\title{
Census based mortality study of pharmaceutical industry workers
}

\author{
J M HARRINGTON ${ }^{1}$ AND P GOLDBLATT ${ }^{2}$ \\ From the Institute of Occupational Health, ${ }^{1}$ University of Birmingham, Birmingham B15 2TT, and Medical \\ Statistics Division, ${ }^{2}$ Office of Population Censuses and Surveys, London, UK
}

\begin{abstract}
This study was designed to investigate whether the mortality of British pharmaceutical industry workers showed any evidence of occupationally related patterns associated with particular sections of the industry with special emphasis on cancers and respiratory diseases. The data were extracted from census schedules by the Office of Population Censuses and Surveys using occupational categories recorded by pharmaceutical workers at the 1961 and 1971 censuses of $\odot$ England and Wales. Subsequent mortality was ascertained through the National Health Service $\circ$ Central Registry. Both cohorts, followed up to the end of 1981, showed a "healthy worker effect," with overall SMRs ranging from 0.77 to 1.04 , though comparison with the employed populations of the longitudinal study reduced this effect by $25 \%$. Evidence of inconsistent excess mortality was noted in small numbers for suicide (SMR 0.91 to 2.79) and cancer of the large intestine (SMR 1.09 to 2.38). There was no clear association between the type of industry and the causes of death investigated. Although the census based study has several methodological shortcomings, there was no evidence, on the basis of this study, to suggest any excess mortality risk from employment in the pharmaceutical industry.
\end{abstract}

The pharmaceutical industry may be considered as a special section of the chemical industry in which many natural and synthetic agents are used to produce therapeutically active products for human consumption. Some of its final products have potentially serious side effects and virtually all are biologically active. Reports of occupationally related health problems within the industry date back nearly $\mathbf{4 0}$ years, and in his early review of the subject Watrous outlined the hazards of handling "crude vegetable drugs," solvents, and the byproducts of organic synthesis. ${ }^{1}$

Since then, various illnesses associated with drug manufacture have been reported. These include allergies, ${ }^{2}$ liver disorders, ${ }^{3}$ adrenocortical suppression, ${ }^{4}$ and feminisation syndromes. ${ }^{5}$ In addition, certain chemotherapeutic agents produced to combat malignancy may themselves carry a risk of neoplasia. ${ }^{6}$ Nevertheless, the question of whether such exposures are translatable into excess mortality for those occupationally exposed remains unanswered, though interest in the subject has led to several recent reviews. $^{7-9}$

Morbidity surveys in the industry have presented major methodological difficulties concerning the

Accepted 15 July 1985 monitoring of exposures in the workforce. ${ }^{10}$ In addi- $\stackrel{\circ}{\stackrel{2}{2}}$ tion, the work carried out in such factories is often of $\overrightarrow{\overrightarrow{0}}$ batch process type. Thus exposure can vary between 3 diverse chemicals in short spaces of time. The work is often undertaken in small manufacturing or formu-o lation units. Some of these investigative difficulties will also be present in any attempt at a review of $\frac{\mathbb{}}{3}$ mortality. Perhaps this is why there appears to be only one such published study. ${ }^{11}$ Thomas and Decoufle 3 . used a proportionate mortality analysis method to 0 describe the cause specific mortality experience of 826 의 plant employees and 249 sales representatives who died between 1954 and 1976 and who were employed by one large United States pharmaceutical firm. The authors noted a significant difference between $=$. observed and expected mortality from suicide and the $N$ proportionate mortality ratios for several cancer sites $\mathrm{N}$ were raised - in particular, respiratory cancer in main- $N$ tenance workers and female production workers. $\omega$ Excess deaths from cancers of the large intestine, $\bar{r}$ breast, and brain were also noted in the total work- 6 force but these excesses were not restricted to any specific subset of workers.

In view of these reports and the advent of the census $\frac{T}{\circ}$ based mortality study ${ }^{12}$ in the United Kingdom it was decided to study the pharmaceutical industry mor $-\frac{?}{\mathrm{D}}$ 
tality experience using this technique. The form chosen was similar to that adopted by Fraser and her co-workers for their study of fertiliser manufacturers ${ }^{13}$ who, as an industry, are similar to the pharmaceutical workers in being employed by many different companies from whom it would be technically difficult to obtain plant specific populations at risk.

\section{Methods}

The study population was derived from data extracted by the Office of Population Censuses and Surveys (OPCS). At both the 1961 and 1971 censuses of England and Wales only a $10 \%$ sample of all records was analysed for some of the questions. Information relating to occupation and industry was among these items, the latter being coded according to the standard industrial classificaton advocated by the Central Statistical Office. ${ }^{1415}$ This coding system enabled OPCS to identify the records of members of industrial groupings.

The present study used data obtained from OPCS on two cohorts each of men and women aged 35 and over who, at the 1961 or 1971 censuses, were identified as employed in industry 272 pharmaceutical chemicals and preparations, who are also occupational orders III, VII, XVIII, XXIV, or XXV. Furthermore, the data were classified by job undertaken in the given industries. Nevertheless, as classification of industries proved difficult to delineate help was enlisted from the Association of British Pharmaceutical Industries who kindly helped in regrouping the companies cited as employers.

The final classification agreed on was thus:

Industry: all companies

Pharmaceutical manufacture/formulation only

Chemical manufacture only

Cosmetic manufacture and retailing

Pharmaceutical and chemical manufacture

Pharmaceutical and cosmetic manufacture

Others and unspecified

The jobs in these industries were grouped as:

Managers

Supervisers

Operatives

Laboratory quality assistants

Maintenance/engineers

Clerical/admininstrative

Sales representatives

Ancilliary

Unspecified

By examining the National Health Service Central Register (NHSCR), OPCS was able to identify and flag the records of the specified workers included in the study. The cause of death, coded according to the 8th revision of the International Classification of Diseases, ${ }^{16}$ could then be ascertained for those pharmaceutical workers who had died. The relevant dates of death were used to calculate the person days at risk from which the expected numbers of deaths by cause were derived using age and calendar period sex specific rates for England and Wales. Ratios of observed and expected deaths were tested for statistical significance assuming a Poisson distribution. No identifiable information on individuals was released by OPCS.

\section{Results}

The 1961 and 1971 cohorts comprised 1472 and 2102 employees respectively and both were followed up to the end of 1981. The trace rates for the two cohorts were $90.0 \%$ (1961) and 96.1\% (1971). Up to the end of 1981657 deaths occurred in the two cohorts. In the 20 years covered by the study for the 1961 cohort 350 men died whereas 428.9 would have been expected on the basis of national rates (table 1). Similar deficits were noted for the 1971 cohort with a marginally lower $\mathrm{O} / \mathrm{E}$ ratio of 0.77 (compared with 0.81 for the 1961 cohort). The only excesses noted in cells containing five or more deaths were for cancer of the large intestine (0:7; E:4.4) and suicide (0:5; E:2.5) both in the 1971 cohort. Otherwise, there were deficits in mortality or the subgroupings produced observed numbers of deaths of less than 5 .

For women a similar pattern of mortality deficits emerged with the exception of "accidents/violence" in the 1961 cohort (0:6; E:2.4) (table 2). Excesses were present for cancer of the large intestine but the numbers were too small to warrant formal statistical testing.

Tables 3 and 4 show analyses of the data by type of industry and for the main causes of death. Again, mortality deficits were the most consistent finding. The only excesses for men worth comment were: the 1961 cohort for "other and unspecified" group for cancers (0:7; E:5) which comprised three cancers of the trachea, bronchus, or lung, one in the bladder, one in the lymphatic/lymphoma grouping, and two others, and the 1971 cohort for circulatory diseases in chemical manufacture (0:13; E:9.2) and in cosmetic manufacture and retailing $(0: 9 ; \mathrm{E}: 6 \cdot 2)$. These excesses were primarily due to ischaemic heart disease. For women, the 1971 cohort showed an excess of deaths from cancer in the "pharmaceutical and chemical manufacture" group of 5.0 observed and 2.8 expected. The cancers were one large bowel, one traçhea, bronchus, or lung, one breast, and two others.

Analysis of the results by job within the industry showed little worthy of note other than that the cancers of the large bowel occurred in managers and 
Table 1 Mortality in pharmaceutical workers (men)

\begin{tabular}{|c|c|c|c|c|c|c|c|c|}
\hline \multirow[t]{2}{*}{ Cause of death } & \multicolumn{4}{|c|}{1961 Cohort $(1961-81)$} & \multicolumn{4}{|c|}{1971 Cohort $(1971-81)$} \\
\hline & $\begin{array}{l}\text { Observed } \\
\text { deaths (0) }\end{array}$ & $\begin{array}{l}\text { Expected } \\
\text { deaths }(E)\end{array}$ & $O / E$ & $\mathrm{CI}+$ & $\begin{array}{l}\text { Observed } \\
\text { deaths (0) }\end{array}$ & $\begin{array}{l}\text { Expected } \\
\text { deaths (E) }\end{array}$ & $O / E$ & $\mathrm{CI}+$ \\
\hline $\begin{array}{l}\text { All causes } \\
\text { All cancers } \\
\text { Large intestine } \\
\text { Trachea/bronchus/lung } \\
\text { Breast } \\
\text { Bladder } \\
\text { Brain } \\
\text { Lymphatic/lymphoma } \\
\text { All circulatory diseases } \\
\text { Ischaemic heart disease } \\
\text { Cerebrovascular disease } \\
\text { All respiratory diseases } \\
\text { Bronchus/emphysema/asthma } \\
\text { All accidents/violence } \\
\text { Suicide }\end{array}$ & $\begin{array}{r}350 \\
86 \\
7 \\
38 \\
0 \\
3 \\
2 \\
5 \\
181 \\
123 \\
27 \\
41 \\
14 \\
12 \\
3\end{array}$ & $\begin{array}{r}428 \cdot 9 \\
100 \cdot 2 \\
6 \cdot 4 \\
41 \cdot 4 \\
0 \cdot 1 \\
4 \cdot 3 \\
1 \cdot 7 \\
5 \cdot 2 \\
218 \cdot 8 \\
134 \cdot 2 \\
44 \cdot 6 \\
65 \cdot 5 \\
31 \cdot 8 \\
12 \cdot 0 \\
3 \cdot 3\end{array}$ & $\begin{array}{l}0.81^{*} \\
0.86 \\
1.09 \\
0.92 \\
0.00 \\
0.70 \\
1.17 \\
0.97 \\
0.83^{*} \\
0.92^{*} \\
0.61^{*} \\
0.63^{*} \\
0.44^{*} \\
1.00 \\
0.91\end{array}$ & $\begin{array}{ll}0.73 & 0.91 \\
0.69 & 1.06 \\
0.44 & 2.25 \\
0.65 & 1.26 \\
0.00 & 36.89 \\
0.14 & 2.04 \\
0.14 & 4.25 \\
0.31 & 2.24 \\
0.71 & 0.96 \\
0.76 & 1.09 \\
0.40 & 0.88 \\
0.45 & 0.85 \\
0.24 & 0.74 \\
0.52 & 1.75 \\
0.19 & 2.66\end{array}$ & $\begin{array}{r}216 \\
56 \\
7 \\
18 \\
1 \\
2 \\
2 \\
4 \\
109 \\
79 \\
15 \\
26 \\
15 \\
9 \\
5\end{array}$ & $\begin{array}{r}280 \cdot 2 \\
70.9 \\
4 \cdot 4 \\
20.5 \\
0.1 \\
2.8 \\
1.6 \\
4.4 \\
142 \cdot 7 \\
93 \cdot 9 \\
25 \cdot 4 \\
36 \cdot 5 \\
16.2 \\
8.9 \\
2.5\end{array}$ & $\begin{array}{c}0.77^{*} \\
0.79 \\
1.58 \\
0.61 \\
11.71 \\
0.72 \\
1.29 \\
0.99 \\
0.76^{*} \\
0.84 \\
0.59^{*} \\
0.71 \\
0.93 \\
1.01 \\
2.00\end{array}$ & $\begin{array}{ll}0.67 & 0.88 \\
0.60 & 1.03 \\
0.64 & 3.28 \\
0.52 & 1.39 \\
0.25 & 55.70 \\
0.09 & 2.58 \\
0.15 & 4.52 \\
0.25 & 2.33 \\
0.63 & 0.92 \\
0.67 & 1.05 \\
0.33 & 0.97 \\
0.47 & 1.04 \\
0.52 & 1.53 \\
0.46 & 1.92 \\
0.65 & 4.67\end{array}$ \\
\hline
\end{tabular}

p $<<0.05$

+ Exact $95 \%$ confidence interval.

Table 2 Mortality in pharmaceutical workers (women)

\begin{tabular}{|c|c|c|c|c|c|c|c|c|}
\hline \multirow[t]{2}{*}{ Cause of death } & \multicolumn{4}{|c|}{1961 Cohort (1961-81) } & \multicolumn{4}{|c|}{1971 Cohort $(1971-81)$} \\
\hline & $\begin{array}{l}\text { Observed } \\
\text { deaths (0) }\end{array}$ & $\begin{array}{l}\text { Expected } \\
\text { deaths }(E)\end{array}$ & $O / E$ & CIt & $\begin{array}{l}\text { Observed } \\
\text { deaths (0) }\end{array}$ & $\begin{array}{l}\text { Expected } \\
\text { deaths }(E)\end{array}$ & $O / E$ & CIt \\
\hline $\begin{array}{l}\text { All causes } \\
\text { All cancers } \\
\text { Large intestine } \\
\text { Trachea/bronchus/lung } \\
\text { Breast } \\
\text { Bladder } \\
\text { Brain } \\
\text { Lymphatic/lymphoma } \\
\text { All circulatory diseases } \\
\text { Ischaemic heart disease } \\
\text { Cerebrovascular disease } \\
\text { All respiratory diseases } \\
\text { Bronchus/emphysema/asthma } \\
\text { All accidents/violence } \\
\text { Suicide }\end{array}$ & $\begin{array}{r}63 \\
10 \\
3 \\
1 \\
3 \\
0 \\
0 \\
0 \\
31 \\
20 \\
7 \\
7 \\
2 \\
6 \\
2\end{array}$ & $\begin{array}{r}70 \cdot 2 \\
20 \cdot 1 \\
1 \cdot 8 \\
2 \cdot 6 \\
4 \cdot 6 \\
0 \cdot 3 \\
0 \cdot 4 \\
1 \cdot 1 \\
33 \cdot 4 \\
15 \cdot 5 \\
9 \cdot 9 \\
7 \cdot 2 \\
2 \cdot 1 \\
2 \cdot 4 \\
0 \cdot 7\end{array}$ & $\begin{array}{l}0.90 \\
0.50^{*} \\
1.62 \\
0.38 \\
0.66 \\
0.00 \\
0.00 \\
0.00 \\
0.93 \\
1.29 \\
0.71 \\
0.97 \\
0.95 \\
2.55 \\
2.79\end{array}$ & $\begin{array}{ll}0.69 & 1.15 \\
0.24 & 0.91 \\
0.34 & 4.87 \\
0.01 & 2.14 \\
0.13 & 1.91 \\
0.00 & 12.30 \\
0.00 & 9.22 \\
0.00 & 3.35 \\
0.63 & 1.32 \\
0.79 & 1.99 \\
0.28 & 1.46 \\
0.39 & 2.00 \\
0.12 & 3.44 \\
0.92 & 5.44 \\
0.35 & 10.32\end{array}$ & $\begin{array}{r}28 \\
13 \\
2 \\
1 \\
1 \\
1 \\
0 \\
0 \\
8 \\
4 \\
2 \\
3 \\
1 \\
0 \\
0\end{array}$ & $\begin{array}{r}30.5 \\
10.4 \\
0.8 \\
1.5 \\
2.6 \\
0.2 \\
0.2 \\
0.6 \\
13.0 \\
6.3 \\
3.6 \\
2.8 \\
0.8 \\
1.2 \\
0.4\end{array}$ & $\begin{array}{l}0.92 \\
1.25 \\
2.38 \\
0.66 \\
0.38 \\
6.33 \\
0.00 \\
0.00 \\
0.61 \\
0.63 \\
0.55 \\
1.06 \\
1.20 \\
0.00 \\
0.00\end{array}$ & $\begin{array}{ll}0.61 & 1.33 \\
0.66 & 2.13 \\
0.30 & 9.03 \\
0.02 & 3.71 \\
0.01 & 2.16 \\
0.13 & 27.85 \\
0.00 & 18.44 \\
0.00 & 6.15 \\
0.27 & 1.21 \\
0.17 & 1.63 \\
0.07 & 2.01 \\
0.22 & 3.13 \\
0.03 & 6.96 \\
0.00 & 3.07 \\
0.00 & 9.22\end{array}$ \\
\hline
\end{tabular}

*p $<0.05$.

+ Exact $95 \%$ confidence interval.

Table 3 Mortality in pharmaceutical workers by industry groupings (men)

\begin{tabular}{|c|c|c|c|c|c|c|c|c|c|c|c|}
\hline \multirow[t]{2}{*}{ Industry grouping } & \multirow{2}{*}{$\begin{array}{l}\text { No } \\
\text { exposed }\end{array}$} & \multicolumn{2}{|c|}{ All causes } & \multicolumn{2}{|c|}{ All cancers } & \multicolumn{2}{|c|}{ All circ dis } & \multicolumn{2}{|c|}{ All resp dis } & \multicolumn{2}{|c|}{ All accid/viol } \\
\hline & & $O$ & $O / E$ & $O$ & $O / E$ & $O$ & $O / E$ & $O$ & $O / E$ & $\bar{O}$ & $O / E$ \\
\hline $\begin{array}{l}\text { Pharm manu/formulation } \\
\text { Chem manu } \\
\text { Cosmetic manu/retailing } \\
\text { Pharm and chem manu } \\
\text { Pharm and cosm manu } \\
\text { Other and unspecified }\end{array}$ & $\begin{array}{r}303 \\
85 \\
121 \\
454 \\
9 \\
48\end{array}$ & $\begin{array}{r}117 \\
31 \\
39 \\
136 \\
3 \\
24\end{array}$ & $\begin{array}{l}1961 \\
0.81 \\
0.72 \\
0.73 \\
0.80 \\
0.74 \\
1.08\end{array}$ & $\begin{array}{r}\text { hort } \\
25 \\
8 \\
9 \\
35 \\
2 \\
7\end{array}$ & $\begin{array}{l}51-81) \\
0.79 \\
0.77 \\
0.72 \\
0.85 \\
1.98 \\
1.41\end{array}$ & $\begin{array}{r}65 \\
14 \\
23 \\
66 \\
1 \\
12\end{array}$ & $\begin{array}{l}0.93 \\
0 \cdot 64 \\
0.85 \\
0 \cdot 78 \\
0 \cdot 50 \\
1.06\end{array}$ & $\begin{array}{r}13 \\
5 \\
4 \\
17 \\
0 \\
2\end{array}$ & $\begin{array}{l}0.59 \\
0.75 \\
0.50 \\
0.69 \\
0.55\end{array}$ & $\begin{array}{l}3 \\
0 \\
2 \\
6 \\
0 \\
1\end{array}$ & $\begin{array}{l}0.81 \\
1.37 \\
1.18 \\
1.77\end{array}$ \\
\hline $\begin{array}{l}\text { Pharm manu/formulation } \\
\text { Chem manu } \\
\text { Cosmetic manu/retailing } \\
\text { Pharm and chem manu } \\
\text { Pharm and cosm manu } \\
\text { Other and unspecified }\end{array}$ & $\begin{array}{r}721 \\
131 \\
66 \\
699 \\
5 \\
42\end{array}$ & $\begin{array}{r}80 \\
20 \\
15 \\
89 \\
0 \\
10\end{array}$ & $\begin{array}{l}1971 \\
0.69 \\
1.10 \\
1.22 \\
0.77 \\
0.68\end{array}$ & $\begin{array}{r}\text { hort } \\
26 \\
6 \\
4 \\
19 \\
0 \\
1\end{array}$ & $\begin{array}{l}1-81) \\
0.86 \\
1.23 \\
1.30 \\
0.66 \\
\overline{0.31}\end{array}$ & $\begin{array}{r}35 \\
13 \\
9 \\
43 \\
0 \\
8\end{array}$ & $\begin{array}{l}0.59 \\
1.41 \\
1.45 \\
0.73 \\
\frac{-}{1.07}\end{array}$ & $\begin{array}{r}8 \\
1 \\
0 \\
16 \\
0 \\
1\end{array}$ & $\begin{array}{l}0.56 \\
0.49 \\
\overline{1.03} \\
\frac{-}{0.41}\end{array}$ & $\begin{array}{l}5 \\
0 \\
0 \\
4 \\
0 \\
0\end{array}$ & $\begin{array}{l}\frac{1.32}{Z} \\
\frac{1.07}{-} \\
-\end{array}$ \\
\hline
\end{tabular}


Table 4 Mortality in pharmaceutical workers by industry groupings (women)

\begin{tabular}{|c|c|c|c|c|c|c|c|c|c|c|c|}
\hline \multirow[t]{2}{*}{ Industry grouping } & \multirow{2}{*}{$\begin{array}{l}\text { No } \\
\text { exposed }\end{array}$} & \multicolumn{2}{|c|}{ All causes } & \multicolumn{2}{|c|}{ All cancers } & \multicolumn{2}{|c|}{ All circ dis } & \multicolumn{2}{|c|}{ All resp dis } & \multicolumn{2}{|c|}{ All accid/viol } \\
\hline & & $O$ & $O / E$ & $O$ & $O / E$ & $O$ & $O / E$ & $O$ & $O / E$ & $O$ & $O / E$ \\
\hline $\begin{array}{l}\text { Pharm manu and formulation } \\
\text { Chem manu } \\
\text { Cosmetic manu/retailing } \\
\text { Pharm and chem manu } \\
\text { Pharm and cosm manu } \\
\text { Other and unspecified }\end{array}$ & $\begin{array}{r}102 \\
19 \\
97 \\
82 \\
6 \\
12\end{array}$ & $\begin{array}{r}18 \\
2 \\
15 \\
23 \\
1 \\
4\end{array}$ & $\begin{array}{r}1961 \\
0.81 \\
0.68 \\
0.77 \\
1.08 \\
0.70 \\
1.39\end{array}$ & $\begin{array}{l}\text { hort } \\
5 \\
0 \\
2 \\
3 \\
0 \\
0\end{array}$ & $\begin{array}{l}1-81) \\
0.78 \\
0.77 \\
0.34 \\
0.54 \\
-\end{array}$ & $\begin{array}{r}10 \\
1 \\
5 \\
11 \\
1 \\
3\end{array}$ & $\begin{array}{l}0.94 \\
0.80 \\
0 \cdot 56 \\
1 \cdot 05 \\
1.40 \\
2 \cdot 15\end{array}$ & $\begin{array}{l}2 \\
0 \\
3 \\
2 \\
0 \\
0\end{array}$ & $\begin{array}{l}0.91 \\
\overline{1.57} \\
0.82 \\
-\end{array}$ & $\begin{array}{l}0 \\
1 \\
1 \\
3 \\
0 \\
1\end{array}$ & $\begin{array}{r}- \\
8.64 \\
1.47 \\
4.49 \\
\overline{11} \cdot 05\end{array}$ \\
\hline $\begin{array}{l}\text { Pharm manu and formulation } \\
\text { Chem manu } \\
\text { Cosmetic manu/retailing } \\
\text { Pharm and chem manu } \\
\text { Pharm and cosm manu } \\
\text { Other and unspecified }\end{array}$ & $\begin{array}{r}203 \\
25 \\
8 \\
106 \\
14\end{array}$ & $\begin{array}{r}18 \\
1 \\
0 \\
9 \\
0 \\
0\end{array}$ & $\begin{array}{l}1971 \\
1.09 \\
0.45 \\
- \\
1 \cdot 13 \\
-\end{array}$ & $\begin{array}{l}8 \\
0 \\
0 \\
5 \\
0 \\
0\end{array}$ & $\begin{array}{l}1-81) \\
1 \cdot 37 \\
- \\
- \\
-\end{array}$ & $\begin{array}{l}5 \\
0 \\
0 \\
3 \\
0 \\
0\end{array}$ & $\begin{array}{l}0.72 \\
\overline{-} \\
0.90 \\
-\end{array}$ & $\begin{array}{l}3 \\
0 \\
0 \\
0 \\
0 \\
0\end{array}$ & $\begin{array}{l}1.99 \\
- \\
- \\
- \\
-\end{array}$ & $\begin{array}{l}0 \\
0 \\
0 \\
0 \\
0 \\
0\end{array}$ & $\begin{array}{l}- \\
- \\
- \\
-\end{array}$ \\
\hline
\end{tabular}

operatives (for industries no consistent excess was noted though three were observed against two expected in the 1961 cohort of pharmaceutical manufacture and formulation group).

In short, there was a consistent deficit for most causes of death analysed, whereas where excesses occurred they were either not restricted to specific job or industry groupings or were too few to warrant statistical analysis.

Whereas the present study is not confined to employed people, the samples selected included a higher proportion of employed people than was to be found in the national population at a comparable time. The reasons why this should be a common feature of census based occupational studies have been discussed in detail elsewhere. ${ }^{17}$ In summary, it is a consequence of the variation in the quality of occupational description at census according to the individuals' economic activity in the week before census; in this instance those in work were more likely to provide a sufficiently detailed description of their job for OPCS to assign them to the industry (pharmaceutical workers) from which the study sample was drawn. This effect was intensified in 1971 by the failure of OPCS to assign occupational codes for those reported as permanently sick in the week before census.

Since the healthy worker effect reflects in mortality terms, the initial state of health of the cohort under study, there is a tendency for this effect to decrease with duration of follow up as the health composition of the surviving cohort changes. In consequence, an appropriate method of adjusting mortality ratios in a study for this effect is to identify the contribution to "expected" mortality in each period of follow up made by sample members according to their economic activity at the time of selection. These values may then be corrected for economic activity and duration of follow up by applying corresponding age specific mor- tality ratios from a nationally representative prospective follow up study. By choosing this method of standardisation, any confounding of temporal patterns of mortality and the healthy worker effect is minimised.

Table 5 shows the result of using figures from the OPCS longitudinal study 1971 census cohort to standardise mortality in this way for both the 1961 and 1971 cohorts. Since the longitudinal study sample has, to date, been followed up for only 10 years, it was possible only to examine the first 10 years mortality experience of the 1961 cohort. The analysis shows that, among men, this phenomenon appears to account for about a quarter of the overall deficit in mortality after 10 years of follow up in both cohorts. As would be expected, this percentage varies by cause of death, with respiratory disease mortality ratios most and cancers least affected. In consequence, after standardisation, there is no significant variation in mortality levels between disease groups. Among women, the numbers of deaths available for analysis are too small to draw firm conclusions, although this form of standardisation points to a slight (nonsignificant) overall excess in mortality in both cohorts, but with no clear disease pattern apparent.

It should be emphasised that the above analysis corrects only for an imbalance in the initial "economic activity" composition of the cohorts. The explanation of the residual deficit in mortality of those identified as workers in the pharmaceutical industry must be explained in terms of other factors influencing health, both real and artefactual, or in the remaining methodological problems of data linkage.

\section{Discussion}

The method used in this study is useful when either factory based records are deficient or a detailed industry based survey is impracticable. It does, however, have serious, though not unique, limitations. The 
Table 5 Mortality in pharmaceutical workers partially adjusted for the healthy worker effect in the first ten years of follow up

\begin{tabular}{|c|c|c|c|c|}
\hline \multirow[t]{2}{*}{ Sex cohort } & \multicolumn{4}{|c|}{ Cause of death } \\
\hline & All causes & All cancers & All circulatory diseases & All respiratory diseases \\
\hline $\begin{array}{l}1961 \text { cohort } \\
\text { (1961-71 mortality) } \\
\text { O } \\
\text { O/E } \\
\text { O/E* } \\
\text { CI } \dagger\end{array}$ & $\begin{array}{l}148 \\
0 \cdot 77 \\
0.83 \\
(0 \cdot 70,0.97)\end{array}$ & $\begin{array}{l}\text { Men } \\
\\
39 \\
0 \cdot 89 \\
0 \cdot 92 \\
(0 \cdot 66,1 \cdot 26)\end{array}$ & $\begin{array}{l}75 \\
0 \cdot 77 \\
0 \cdot 81 \\
(0 \cdot 64,1 \cdot 02)\end{array}$ & $\begin{array}{l}17 \\
0.59 \\
0.71 \\
(0 \cdot 41,1 \cdot 13)\end{array}$ \\
\hline $\begin{array}{l}1971 \text { cohort } \\
\text { (1971-81 mortality) } \\
\text { O } \\
\text { O/E } \\
\text { O/E* } \\
\text { CI } \dagger\end{array}$ & $\begin{array}{l}216 \\
0 \cdot 77 \\
0 \cdot 83 \\
(0 \cdot 72,0.95)\end{array}$ & $\begin{array}{l}56 \\
0.79 \\
0.81 \\
(0.58,1.00)\end{array}$ & $\begin{array}{l}109 \\
0.75 \\
0.81 \\
(0.67,0.98)\end{array}$ & $\begin{array}{l}26 \\
0.71 \\
0.84 \\
(0 \cdot 55,1 \cdot 23)\end{array}$ \\
\hline $\begin{array}{l}1961 \text { cohort } \\
\text { (1961-71 mortality) } \\
\text { O } \\
\text { O/E } \\
\text { O/E* } \\
\text { CI } \dagger\end{array}$ & $\begin{array}{l}27 \\
1.04 \\
1.15 \\
(0 \cdot 76,1 \cdot 68)\end{array}$ & $\begin{array}{l}3 \\
0.42 \\
0.43 \\
(0.09,1 \cdot 25)\end{array}$ & $\begin{array}{l}15 \\
1 \cdot 26 \\
1.46 \\
(0 \cdot 82,2 \cdot 40)\end{array}$ & $\begin{array}{l}2 \\
0 \cdot 83 \\
1 \cdot 11 \\
(0 \cdot 13,4 \cdot 01)\end{array}$ \\
\hline $\begin{array}{l}1971 \text { cohort } \\
\text { (1971-81 mortality) } \\
\mathrm{O} \\
\mathrm{O} / \mathrm{E} \\
\mathrm{O} / \mathrm{E}^{*} \\
\mathrm{CI} \dagger\end{array}$ & $\begin{array}{l}28 \\
0 \cdot 92 \\
1.09 \\
(0 \cdot 72,1 \cdot 57)\end{array}$ & $\begin{array}{l}13 \\
1 \cdot 25 \\
1 \cdot 30 \\
(0 \cdot 69,2 \cdot 22)\end{array}$ & $\begin{array}{l}8 \\
0.61 \\
0.75 \\
(0.33,1.49)\end{array}$ & $\begin{array}{l}3 \\
1.06 \\
1.58 \\
(0 \cdot 33,4 \cdot 62)\end{array}$ \\
\hline
\end{tabular}

* Ratio of observed to expected deaths after adjustment of numbers of expected deaths to take account of economic activity in the week before census. Adjustment factors were obtained from observation of comparable mortality in the OPCS longitudinal study 1971 census cohort during the period 1971-81.

+Exact $95 \%$ confidence interval for adjusted mortality ratios.

main drawback lies in the fact that the occupation stated on the census form relates only to the job currently done and this could be irrelevant to the long term or lifetime "exposure." Such an approach, therefore, can be used only in industries with relatively stable working populations (which, anecdotally, the pharmaceutical industry does possess). Nevertheless, examination of the occupation recorded at death provided some evidence of prolonged employment in the relevant industries (table 6). There was an identical coding match between the occupation stated at census and that recorded at death in $38.1 \%$ of the deaths in the study. An additional $37 \cdot 1 \%$ of death certificate job codings were compatible (maintenance engineer, process worker, for example) but did not contain any industry information. Only $16.1 \%$ of those who died had definitely changed job whereas of the remaining 57 deaths, 17 were described as "wives"/"widows" and in 39 no information was given. The present analysis is thus proportionately similar to that cited in the census based fertiliser manufacturers study. ${ }^{13}$ Even so, the linkage of stated occupation at death to stated occupation in life has inherent information bias. Furthermore, no detailed exposure data were available, only a broad subclassification of the industry.
The results outlined have showed a mortality deficit $\stackrel{\circ}{\circ}$ for most causes of death analysed, a finding consistent $\overrightarrow{\overrightarrow{0}}$ with the healthy worker effect often found when an 3 employed population's mortality is compared with national patterns. ${ }^{18}$ Such an effect is, in reality, a methodological flaw. It reflects the incomparability of the compared populations-a matter of 3 confounding-and is not necessarily a result of incomparability of the effects nor of information. ${ }^{19}$.

Two excess mortality patterns of note are those forô suicide and cancer of the large intestine. Excess suicide rates have been noted in several studies of "profes-윽 sional" populations, particularly those in the healthy $>$ industry where access to drugs may be relatively easy. ${ }^{\circ 0}$. A twofold excess was found in the Thomas and

Table 6 A comparison of occupational codings at census and on the death certificate

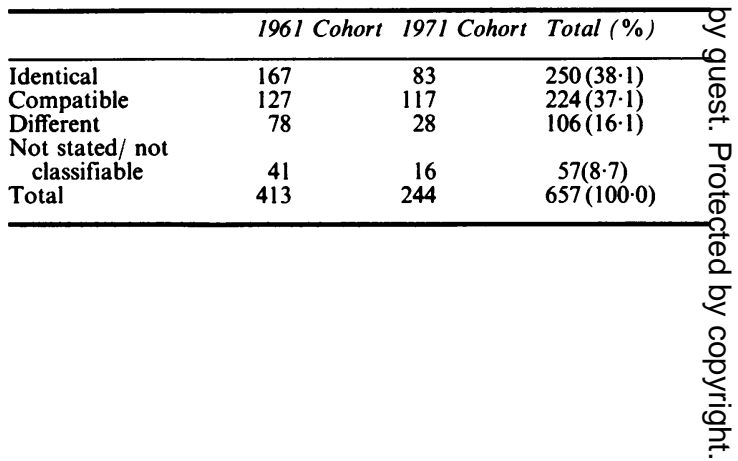


Decoufle study, ${ }^{11}$ but the observed numbers in the present study are too small to allow for substantive causal suggestions. Six of the 10 suicides occurred in operatives against an expected $2 \cdot 5$, whereas the distribution by industry grouping was commensurate with the population base for each industry.

Cancer of the large intestine was found in excess in the previous mortality study cited, but the explanation was thought to be non-occupational. In the present study 19 such deaths were noted. They were largely restricted to the managerial and operative groups, though spread widely over the industry. No obvious occupational factors can be invoked. It is interesting to note that the excesses of brain ${ }^{20}$ or haemopoeitic ${ }^{21}$ neoplasms noted in other studies of workers exposed to organic chemicals have not been noted here, though the expected numbers were small.

Given the relatively high incidence of allergic disorders of the lung and skin associated with some parts of the pharmaceutical industry, it is satisfying to note that such acute pulmonary reactions are not translated into excess mortality for respiratory diseases.

In the final analysis this mortality study of pharmaceutical industry workers, despite its methodological shortcomings, does not appear to indicate any consistently raised cause specific death rates and where some excesses were noted there was no clear cut occupational explanation for the findings. Further follow up of the cohorts would be required to clarify further the putative diminishing influence of the healthy worker effect.

We gratefully acknowledge support for the study through a research grant from the Health and Safety Executive. The study would not, however, have been possible without the help of the staff of the census division, OPCS, and of the NHSCR, Southport. We are also grateful to the Association of British Pharmaceutical Industries for their help in the planning of this study and particularly for their guidance over the classification of the industries included in the analysis.

\section{References}

${ }^{1}$ Watrous RM. Health hazards of the pharmaceutical industry. Br $J$ Ind Med 1947;4:111-25.

${ }^{2}$ Parkes WR. Occupational lung disorders. 2nd ed. London: Butterworth, 1982.

${ }^{3}$ Jeney E, Bartha F, Kondor L, Szendrai S. Prevention of industrial tetrachloroethane intoxication, part III. Egeszegtudomony 1957;1:155-64.

${ }^{4}$ Newton RW, Browning MCK, Nicholson PC, Mowat DAE. Adrenocortical suppression in workers employed in manufacturing synthetic glucocorticosteroids: solutions to a problem. $\mathrm{Br} J$ Ind Med 1982;39:179-82.

${ }^{5}$ Harrington JM, Stein GF, Rivera RO, De Morales AV. Occupational exposure to synthetic oestrogens: a survey of plant employees. Arch Environ Health 1978;33:12-5.

${ }^{6}$ International Agency for Research on Cancer. Supplement 2 to the monograph series. Lyon: IARC, 1982.

${ }^{7}$ Alessio L, Banderali S, Farina G. Occupational exposure to drugs: general considerations. Med Lav 1976;67:221-3.

${ }^{8}$ Loriot J, Benichou G, Raix A, Proteau J, Philbert M. Industry pathology in laboratories and the pharmaceutical industry. Archives de Maladie Professionelles 1976;37:10-1, 790-5.

${ }^{9}$ Harrington JM. The health industry. In: McDonald JC, ed. Advances in occupational health. Vol 1. London: Churchill Livingstone, 1981:75-84.

${ }^{10}$ Harrington JM. Occupational exposure to synthetic oestrogens: some methodological problems. Scand J Work Environ Health 1982;8:suppl 1.

${ }^{11}$ Thomas TLL, Decoufle P. Mortality among workers employed in the pharmaceutical industry: a preliminary investigation. $J$ Occup Med 1979;21:619-23.

12 Alderson M. Cancer mortality in male hairdressers. J Epidemiol Community Health 1981;36:69-80.

${ }^{13}$ Fraser P, Chilvers C, Goldblatt P. Census based mortality study of fertiliser manufacturers. Br J Ind Med 1982;39:323-9.

${ }^{14}$ Central Statistical Office. Standard industrial classification. 2nd ed. London: HMSO, 1958.

${ }^{15}$ Central Statistical Office. Standard industrial classification. 3rd ed. London: HMSO, 1968.

${ }^{16}$ World Health Organisation, International classification of diseases. 8th rev. Geneva, WHO, 1969.

${ }^{17}$ Fox AJ, Goldblatt PO, Adelstein AM. Selection and mortality differentials. J Epidemiol Community Health 1982;36:69-79.

${ }^{18}$ McMichael AJ. Standardised mortality ratios and the "healthy worker effect": scratching beneath the surface. J Occup Med 1976;18:165-8.

${ }^{19}$ Wang JD, Miettinen OS. Occupational mortality studies: principles of validity. Scand J Work Environ Health 1982;8:153-8.

${ }^{20}$ Harrington JM, Oakes D. Mortality study of British pathologists 1974-80. Br J Ind Med 1984;41:188-91.

${ }^{21}$ Harrington JM. Cancer and the health industry. J Soc Occup Med 1983;33:114-8. 